\title{
Isolation of Neisseria meningitidis from the urethra, cervix, and anal canal: Further observations
}

\author{
K. F. GIVAN, B. W. THOMAS, AND A. G. JOHNSTON \\ From the Women's College Hospital, Toronto, Canada
}

SUMMARY Neisseria meningitidis was recovered from the urethra of nine and from the anal canal of seven men, and from the cervix of two women. Twelve of the 16 men were admitted homosexuals. Seven men had no symptoms, while the remainder had mild to moderate symptoms. One woman was asymptomatic and the other was in hospital with acute salpingitis. Reports of previous isolations of meningococci from the urethra, cervix, or anal canal are reviewed. It is concluded that in men, these infections are usually mild and self-limited, but in women, meningococcal genital infections frequently proceed to severe disease.

\section{Introduction}

Before 1971 the isolation of Neisseria meningitidis from the genitourinary tract or the anal canal was an uncommon event (Murray, 1933; Carpenter and Charles, 1942; Armytage, 1944), but recently several papers have been published describing the isolation of meningococci from unusual sites (Gregory and Abramson, 1971; Keys et al., 1971; Sunderland et al., 1972; Brown et al., 1973; Volk and Kraus, 1973; Lewis and Alexander, 1974; Givan and Keyl, 1974; Fallon and Robinson, 1974; Beck et al., 1974; Faur et al., 1975; Morgan et al., 1976; Willmott, 1976). We have previously described the isolation of this organism from the cervix and urethra of six individuals (Givan and Keyl, 1974). Eighteen additional patients from whom the organism was isolated from the cervix, urethra, or anal canal are described and the clinical significance of these findings is discussed.

\section{Methods}

The 16 men all attended the hospital's Venereal Disease Treatment Clinic between April 1974 and May 1976. One woman was seen at a gynaecology clinic, while the other visited her private physician.

Urethral swabs were taken from all the men; if they were homosexual, throat and rectal cultures were generally taken as well. Cervical swabs only were taken from the two women.

Address for reprints: Dr Kathleen Givan, Division of Microbiology, Women's College Hospital, Toronto, Ontario M5S 1B2, Canada.

Received for publication 3 November 1976
Swabs taken at the clinic were plated directly on to Thayer-Martin medium, while those taken elsewhere were placed in Amies's transport medium (Amies, 1967) and plated on to Thayer-Martin medium in the laboratory. Cultures were incubated in 5 to $10 \% \mathrm{CO}_{2}$ at a temperature of $36^{\circ} \mathrm{C}$ and examined 48 hours later. Strains were identified as meningococci by colonial appearance, Gram-stain morphology, positive oxidase reaction, faint nonspecific fluorescence with Neisseria gonorrhoeae antiserum (Difco) compound with brilliant positive controls, fermentation of $1 \%$ glucose and maltose but not sucrose in cystine trypticase agar (BBL), and by lack of B-D-galactosidase using $1 \% \mathrm{O}$-nitrophenol-B-D-galactopyranoside in buffered peptone broth as test system. Ten of 18 isolates were sent to the Bacteriology Reference Laboratory, Laboratory Services Branch, Ontario Ministry of Health, for confirmation. The laboratory also serogrouped the organisms.

\section{Results}

During a period of 26 months, $N$. meningitidis was isolated from the urethra in nine men, from the anal canal in seven, and from the cervix in two women. Table 1 summarises the clinical findings of these 18 individuals.

Twelve of the 16 men studied were homosexuals. Those who had symptoms were treated with either oral tetracycline or erythromycin $(8 \mathrm{~g}$ taken over six days). The clinical diagnosis in these patients was gonorrhoea or non-specific urethritis. Six of eight patients treated with tetracycline who returned for 
Table 1 Isolation of $\mathrm{N}$. meningitidis from cervix, urethra, and anal canal

\begin{tabular}{|c|c|c|c|c|c|c|c|}
\hline \multirow[b]{2}{*}{ Patient } & \multirow[b]{2}{*}{$\begin{array}{l}\text { Age } \\
\text { (years) }\end{array}$} & \multirow[b]{2}{*}{$\operatorname{Sex}$} & \multicolumn{3}{|c|}{ Results of cultures } & \multirow[b]{2}{*}{ Symptoms } & \multirow[b]{2}{*}{ Treatment and outcome } \\
\hline & & & Throat & $\begin{array}{l}\text { Cervix or } \\
\text { urethra }\end{array}$ & $\begin{array}{l}\text { Anal } \\
\text { canal }\end{array}$ & & \\
\hline 1 & 23 & $\mathbf{M}(\mathrm{HS})^{*}$ & - & + & - & Urethral discharge & $\begin{array}{l}\text { Rx tetracycline-discharge persisted, cultures became } \\
\text { negative }\end{array}$ \\
\hline 2 & 25 & $\mathbf{M}$ & NT $\dagger$ & + & NT & Mild discharge & $\begin{array}{l}\text { Rx tetracycline-symptoms disappeared, cultures became } \\
\text { negative }\end{array}$ \\
\hline 3 & 28 & $\mathbf{M}$ & NT & + & NT & No symptoms & $\begin{array}{l}\text { Repeat cultures positive- }-R x \text { tetracycline, cultures } \\
\text { became negative }\end{array}$ \\
\hline 4 & 19 & $\mathbf{M}$ & NT & + & NT & Discharge & Rx tetracycline-'cured', cultures became negative \\
\hline 5 & 25 & M(HS) & NT & + & NT & Discharge & Rx tetracycline-'cured', cultures became negative \\
\hline 6 & 26 & M(HS) & NT & + & NT & No symptoms & Lost to follow-up \\
\hline 7 & 22 & M(HS) & NT & + & NT & No symptoms & Rx tetracycline-cultures became negative \\
\hline 8 & 26 & M(HS) & + & + & NT & $\begin{array}{l}\text { Discharge-tender } \\
\text { inguinal nodes }\end{array}$ & Rx tetracycline-lost to follow-up \\
\hline 9 & 22 & & NT & + & NT & Discharge & Rx tetracycline-lost to follow-up \\
\hline 10 & 16 & M(HS) & NT & - & + & Mild rectal burning & $\begin{array}{l}\text { Rx tetracycline-symptoms continued, cultures remained } \\
\text { positive, re-treated }\end{array}$ \\
\hline 11 & 25 & M(HS) & + & - & + & No symptoms & Lost to follow-up \\
\hline 12 & 27 & M(HS) & + & - & + & No symptoms & No treatment-lost to follow-up \\
\hline 13 & 26 & M(HS) & + & - & + & Anal itching & Rx tetracycline-'cured', cultures negative \\
\hline 14 & 25 & M(HS) & + & - & + & Rectal discharge & $\begin{array}{l}\text { Rx erythromycin-symptoms disappeared, culture } \\
\text { remained positive }\end{array}$ \\
\hline 15 & 24 & M(HS) & + & - & + & No symptoms & $\mathbf{R x}$ tetracycline-lost to follow-up \\
\hline 16 & 28 & M(HS) & + & - & + & No symptoms & No treatment-cultures remained positive \\
\hline 17 & 21 & $\mathbf{F}$ & NT & + & NT & Discharge, pelvic pain & Hospitalised for pelvic inflammatory disease \\
\hline 18 & 22 & $\mathbf{F}$ & NT & + & NT & None & Lost to follow-up \\
\hline
\end{tabular}

*HS-homosexual †NT-not tested

follow-up cultures were 'cured'-that is, their symptoms disappeared and cultures taken twice at weekly intervals after treatment from the men and three times from the women-were negative for meningococci. Two patients were re-treated because symptoms persisted. One woman in the series was asymptomatic and received no treatment but another required hospitalisation. This patient developed bleeding, vaginal discharge, and lower abdominal pain 10 days after the insertion of a copper intrauterine device. The intrauterine device was removed and a cervical culture taken, which yielded $N$. meningitidis. She was treated with erythromycin for seven days. However, her symptoms persisted and she was admitted to hospital with a diagnosis of acute pelvic inflammatory disease. A vaginal culture taken on admission did not yield Neisseria species. In hospital she was treated with parenteral clindamycin because she was allergic to several other chemotherapeutic agents; she was discharged on the seventh day.

The reference laboratory reported that two strains were Group B, two were Group Y, while six strains did not fall into any group although they were confirmed as meningococci.

\section{Discussion}

There are now reports in the literature of 84 patients from whom $N$. meningitidis was isolated from the cervix, urethra, or anal canal. Clinical details are available for 46 of these, and it is possible to make some conclusions about the natural history of this disease. Table 2 summarises the data.

It is apparent that there is a predominance of men in these reports: $58(70 \%)$ of 84 patients. Of the 30 men for whom there are clinical details, 17 were homosexuals. Twelve $(40 \%)$ of these had no symptoms while the remainder had mild to moderate symptoms.

The three female children described all had symptoms of vaginitis, but these symptoms disappeared with little or no specific treatment.

It appears that the infection is more severe in women. Only four of 13 adult women from whom this organism was isolated were asymptomatic, while five had generalised disease-including sepsis, arthritis, endometritis, or salpingitis - and the remainder had severe vaginitis or cervicitis. The newborn infant of one patient died of meningococcal sepsis at two days of life (Sunderland et al., 1972).

It is by no means clear that the symptoms noted by the men were caused by the presence of $N$. meningitidis.

In our series, urethral discharge persisted after treatment although cultures became negative in patient 1, while rectal discharge disappeared but cultures remained positive in another, patient 14 . Among patients who had complaints, symptoms were often vague and non-specific. Few of the reported patients received treatment which could be considered adequate to eradicate the organism, yet 
Table 2 Review of reported N. meningitidis infections of genitourinary tract and anal canal

\begin{tabular}{|c|c|c|c|c|c|}
\hline \multirow[b]{2}{*}{ Author } & \multicolumn{2}{|c|}{ No. of patients } & \multirow[b]{2}{*}{ Infected site } & \multirow[b]{2}{*}{ Symptoms } & \multirow[b]{2}{*}{ Outcome } \\
\hline & Male & Female & & & \\
\hline $\begin{array}{l}\text { Carpenter and Charles, } \\
1942\end{array}$ & 6 & 1 & $\begin{array}{l}\text { Urethra } \\
\text { Cervix }\end{array}$ & $\begin{array}{l}\text { Urethritis } \\
\text { Cervicitis }\end{array}$ & $\begin{array}{l}\text { Not known } \\
\text { Not known }\end{array}$ \\
\hline Armytage, 1944 & & 1 (child) & Vagina & Vaginitis & Not known \\
\hline Keys et al., 1971 & & $\begin{array}{l}1 \\
1\end{array}$ & $\begin{array}{l}\text { Blood, joint, cervix } \\
\text { Cervix }\end{array}$ & $\begin{array}{l}\text { Sepsis and arthritis } \\
\text { Arthritis }\end{array}$ & $\begin{array}{l}\text { Cured by intravenous } \\
\text { penicillin } \\
\text { Cured by intravenous } \\
\text { penicillin }\end{array}$ \\
\hline $\begin{array}{l}\text { Gregory and Abramson, } \\
1971\end{array}$ & & 1 (child) & Vagina & Vaginitis & Spontaneous improvement \\
\hline Sunderland et al., 1972 & & 1 & $\begin{array}{l}\text { Cervix; cerebrospinal fluid } \\
\text { and lung of neonate }\end{array}$ & $\begin{array}{l}\text { None in mother, neonatal } \\
\text { sepsis }\end{array}$ & Infant died \\
\hline Volk and Kraus, 1973 & 1 & & Urethra & None & $\begin{array}{l}\text { Exposed to GC but did not } \\
\text { contract }\end{array}$ \\
\hline $\begin{array}{l}\text { Lewis and Alexander, } \\
1974\end{array}$ & & 3 & Cervix or vagina & None & Not known \\
\hline Beck et al., 1974 & 1 (HS)* & & $\begin{array}{l}\text { Urethra } \\
\text { Rectum }\end{array}$ & $\begin{array}{l}\text { Urethritis } \\
\text { Proctitis }\end{array}$ & $\begin{array}{l}\text { Cured by ampicillin } \\
\text { Rx cotrimoxazole }\end{array}$ \\
\hline $\begin{array}{l}\text { Fallon and Robinson, } \\
1974\end{array}$ & & 1 (child) & Vagina & Vaginitis & Spontaneous improvement \\
\hline Givan and Keyl, 1974 & $\begin{array}{l}4(\mathrm{HS}) \\
1\end{array}$ & 1 & $\begin{array}{l}\text { Cervix } \\
\text { Urethra } \\
\text { Urethra }\end{array}$ & $\begin{array}{l}\text { Cervicitis urethritis } \\
\text { None } \\
\text { Urethritis }\end{array}$ & $\begin{array}{l}\text { Cured with tetracycline } \\
\text { Not known } \\
\text { Rx tetracycline-lost }\end{array}$ \\
\hline Faur et al., 1975 & $\begin{array}{l}12 \\
16\end{array}$ & 10 & $\begin{array}{l}\text { Cervix } \\
\text { Urethra } \\
\text { Anal canal }\end{array}$ & $\begin{array}{l}\text { Not known } \\
\text { Not known } \\
\text { Not known }\end{array}$ & $\begin{array}{l}\text { Not known } \\
\text { Not known } \\
\text { Not known }\end{array}$ \\
\hline Morgan et al., 1976 & & 1 & Blood & Postpartum endometritis & $\mathbf{R x}$ intravenous penicillin \\
\hline Willmott, 1976 & & $\begin{array}{l}1 \\
1\end{array}$ & $\begin{array}{l}\text { Cervix } \\
\text { Cervix }\end{array}$ & $\begin{array}{l}\text { Salpingitis } \\
\text { Pelvic inflammatory disease }\end{array}$ & Cured by ampicillin \\
\hline Present series & $\begin{array}{l}6(3 \mathrm{HS}) \\
3(2 \mathrm{HS}) \\
3(1 \mathrm{HS}) \\
4(\mathrm{HS})\end{array}$ & 1 & $\begin{array}{l}\text { Cervix } \\
\text { Urethra } \\
\text { Urethra } \\
\text { Rectum } \\
\text { Rectum }\end{array}$ & $\begin{array}{l}\text { None } \\
\text { Urethritis } \\
\text { None } \\
\text { Proctitis } \\
\text { None }\end{array}$ & $\begin{array}{l}\text { See } \\
\text { Text }\end{array}$ \\
\hline
\end{tabular}

*HS-homosexual

the infections usually disappeared soon after treatment. It is possible that carriage of this organism in the urethra or anal canal is self-limited. Extended follow-up examinations of these patients would be valuable to clarify this point. Antibiotic treatment of male homosexual patients seldom seems necessary. Consideration might be given to treating heterosexual men to prevent transmission to women as progression to severe systemic illness is common in women, and treatment even in the absence of symptoms seems justified.

The mode of acquisition of these organisms has not been defined. Several authors have commented that the isolation of meningococci from the genitourinary tract and anal canal has coincided with a high pharyngeal carriage rate in the community (Armytage, 1944; Givan and Keyl, 1974; Faur et al., 1975). Sexual transmission seems the likely explanation for most cases.

The large percentage of homosexual men in the reported cases must be more than coincidence and the varied sexual practices of these individuals would increase the chance of transmission.

Auto-infection via the hands is another possible mode, and was considered the way in which the three children acquired their infections. To explain the presence of these organisms in the anal canal, one could suggest that they originated in the oropharynx and were swallowed. All six of the anal carriers in our series who had throat cultures taken carried the organism in their pharynx. It has not been established whether the delicate meningococcus can survive transit through the gastrointestinal tract.

The observed increase in these infections is probably real, and not based solely on increased awareness by clinicians or by more thorough differentiation of Neisseria species in laboratories. Faur et al. (1975) noted an eightfold increase in genital and anal isolates of meningococci between 1973 and 1975 , while the total volume of cultures examined remained about the same. Isolation of 
meningococci from the anal canal is an even more recent phenomenon. The first infection was reported in 1974 (Beck et al., 1974). All the isolations reported by Faur et al. (1975) occurred during the latter part of their study, while five of our seven recoveries were made during the first four months of 1976. It is hoped that further studies will clarify these unusual meningococcal infections.

We wish to thank Dr Irene Abramowicz for permission to include patient 17 in this report. Thanks are also extended to Dr S. Toma, Chief Bacteriologist, Laboratory Services Branch, Ontario Ministry of Health, and his staff who confirmed the identity of and serogrouped the meningococcal isolates.

\section{References}

Amies, C. R. (1967). A modified formula for the preparation of Stuart's transport medium. Canadian Journal of Public Health, 58, 296-300.

Armytage, J. (1944). Unusual infections with the Neisseria. Medical Journal of Australia, 2, 360-361.

Beck, A., Fluker, J. L., and Platt, D. J. (1974). Neisseria meningitidis in urogenital infection. British Journal of Venereal Diseases, 50, 367-369.

Brown, W. J., Kraus, S. J., and Arko, R. J. (1973). Chimpanzee urethral meningococci. British Journal of Venereal Diseases, 49, 88.
Carpenter, C. M., and Charles R. (1942). Isolation of meningococcus from the genitourinary tract of seven patients. American Journal of Public Health and the Nation's Health, 32, 640-643.

Fallon, R. J., and Robinson, E. T. (1974). Meningococcal vulvovaginitis. Scandinavian Journal of Infectious Diseases, 6, 295-296.

Faur, Y. C., Weisburd, M. H., and Wilson, M.E. (1975). Isolation of Neisseria meningitidis from the genito-urinary tract and anal canal. Journal of Clinical Microbiology, 2, 178-182.

Givan, K. F., and Keyl, A. (1974). The isolation of Neisseria species from unusual sites. Canadian Medical Association Journal, 111, 1077-1079.

Gregory, J. E., and Abramson, E. (1971). Meningococci in vaginitis. American Journal of Diseases of Children, 121, 423.

Keys, T. F., Hecht, R. H., and Chow, A. W. (1971). Endocervical Neisseria meningitidis with meningococcemia. New England Journal of Medicine, 285, 505-506.

Lewis, J. F., and Alexander, J. J. (1974). Isolation of Neisseria meningitidis from the vagina and cervix. American Journal of Clinical Pathology, 61, 216-217.

Morgan, J. R., Fedder, J., and Smith, J. A. (1976). Postpartum infection with meningococcemia. Canadian Medical Association Journal, 114, 294.

Murray, E. G. D. (1933). Meningococcus infection of the male urogenital tract and the liability to confusion with gonococcus infection. Urologic and Cutaneous Review, 43, 739-741.

Sunderland, W. A., Harris, H. H., Spence, D. A., and Lawson, H. W. (1972). Meningococcemia in a newborn infant whose mother had meningococcal vaginitis. Journal of Pediatrics, 81, 856.

Volk, J., and Kraus, S. J. (1973). Asymptomatic meningococcal urethritis. Possible protective value against gonococcal infection by bacteriocin production. British Journal of Venereal Diseases, 49, 511-512.

Willmott, F. E. (1976). Meningococcal salpingitis. British Journal of Venereal Diseases, 52, 182-183. 